\title{
DECLARAÇÃO DE REVISÃO
}

Prezados senhores,

Declaro, para os devidos fins, que realizei a correção ortográfica e gramatical do artigo "TRABALHO E PREVIDÊNCIA SOCIAL: AS LACUNAS DE PROTEÇÃO SOCIAL NA SEGURIDADE SOCIAL", de Dolores Sanches Wünsch, Jussara Maria Rosa Mendes e Juliana Martins.

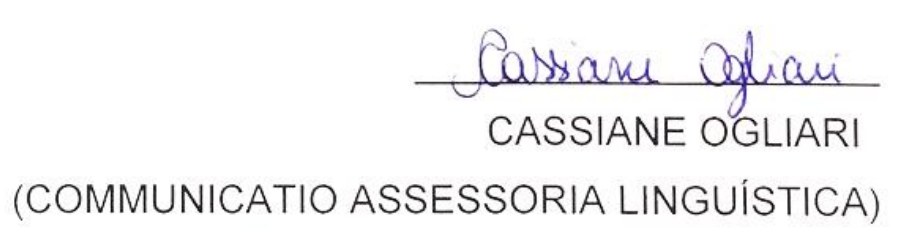

Nome: Cassiane Ogliari

CPF: $\underline{010.725 .770-03}$

Formação: Mestre em Linguistica Aplicada (UNISINOS-2013) / Especialista em Tradução de Inglês (UGF-2012) / Licenciada em Letras - Português e Inglês (UNISINOS-2008) 